\title{
KARAKTERISTIK DAN ANALISIS FINANSIAL USAHATANI TOMAT DI KABUPATEN LOMBOK TIMUR
}

\section{CHARACTERISTICS AND FINANCIAL ANALYSIS OF TOMATO FARMING IN EAST LOMBOK DISTRICT}

\author{
Dudi Septiadi $^{1 *}$, Andi Iva Mundiyah ${ }^{2}$ \\ 1, 2, Program Studi Agribisnis, Universitas Mataram, Kota Mataram, Indonesia \\ *Email Penulis Korespondensi: dudi@unram.ac.id
}

\begin{abstract}
Abstrak
Tomat merupakan jenis komoditas hortikultura dengan tingkat harga yang terus berfluktuasi. Tujuan Penelitian ini adalah untuk; 1) mendeskripsikan karakteristik usahatani tomat di Kabupaten Lombok Timur; 2) menganalisis tingkat pendapatan petani tomat di Kabupaten Lombok Timur; 3). Menganalisis tingkat kelayakan finansial usahatani tomat di Kabupaten Lombok Timur. Metode penelitian yang digunakan adalah metode observasi lapangan dengan pendekatan kualitatif - deskriptif. Jumlah responden pada penelitian ini adalah petani tomat sebanyak 40 orang. Teknik pengambilan data yang digunakan yaitu teknik survey dan wawancara menggunakan kuesioner. Hasil penelitian menunjukkan bahwa usahatni tomat di Kabupaten Lombok Timur diusahakan oleh petani dengan rata-rata usia produktif dengan pengalaman usahatani yang cukup lama, akan tetapi memiliki tingkat pendidikan yang rendah dan memiliki rata-rata luas areal panen tomat yang juga rendah $(0,16$ hektar). Berdasarkan analisis finansial, usahatani tomat di Kabupaten Lombok Timur dinyatakan memperoleh keuntungan, karena total nilai penerimaan lebih tinggi dibandingkan dengan total biaya broduksi. Berdasarkan analisis R/C ratio, usahatani tomat di Kabupaten Lombok Timur layak untuk diusahakan, karena nilai $\mathrm{R} / \mathrm{C}$ ratio sebesar 3,3> 1 (kategori layak diusahakan).
\end{abstract}

Kata Kunci : Analisis Pendapatan, Kelayakan Usahatani, Tomat.

\begin{abstract}
Tomatoes are a type of horticultural commodity with prices that continue to fluctuate. The purpose of this research is to; 1) describe the characteristics of tomato farming in East Lombok Regency; 2) analyze the income level of tomato farmers in East Lombok Regency; 3). Analyzing the level of financial feasibility of tomato farming in East Lombok Regency. The research method used is the observation method with a qualitative - descriptive approach. The number of respondents in this study were 40 tomato farmers. Data collection techniques used are survey techniques and interviews using questionnaires. The results showed that tomato farming in East Lombok Regency was cultivated by farmers with an average productive age with long farming experience, but had a low level of education and had a low average tomato harvest area (0.16 hectares). ). Based on financial analysis, tomato farming in East Lombok Regency is declared to be profitable, because the total revenue value is higher than the total production cost. Based on the $\mathrm{R} / \mathrm{C}$ ratio analysis, tomato farming in East Lombok Regency is feasible to cultivate, because the R/C ratio value is 3.3> 1 (category feasible to cultivate).
\end{abstract}

Keywords: Income Analysis, Feasibility of Farming, Tomatoes. 


\section{PENDAHULUAN}

Salah satu sub sektor pertanian yang menjadi pusat perhatian dan sangat potensial untuk dikembangkan adalah sub sektor hortikultura. Menurut Irsan (2010) dalam pengembangan sub sektor hortikultura dibedakan atas buah-buahan, tanaman hias, sayur-sayuran, dan tanaman obat-obatan. Diantara subsektor horikultura tersebut, usahatani sayuran memberi kontribusi penting bagi ketahanan pangan dan gizi masyarakat (Septiadi dan Nursan, 2020). Indonesia dengan potensi sumber daya lahan dan agroklimat yang beragam berpeluang untuk mengembangkan berbagai tanaman sayuran (Tanaya et al, 2020). Menurut Fitri et al, (2018), salah satu tanaman sayuran yang memeberikan kontribusi produksi terbesar terhadap total produksi sayuran di Indonesia yaitu tomat, yaitu sebesar 7,69 persen.

Tanaman tomat (Lycopersicum esculentum Mill), tumbuh secara alami di negara asalnya yaitu di Peru dan Ekuador kemudian menyebar ke seluruh Amerika, terutama di daerah beriklim tropis. Orang Eropa dan Asia mengenal tanaman tomat pada tahun 1523. Namun, saat itu, tanaman tomat dianggap beracun dan dibudidayakan hanya sebagai tanaman hias dan sebagai obat kanker. Tomat ditanam setelah Belanda tiba di Indonesia. Hal ini menunjukkan bahwa tomat tersebar di seluruh dunia, baik tropis maupun subtropis. opik (Cahyono, 1998).

Produksi dan harga yang tidak stabil menyebabkan fluktuasi pendapatan petani tomat. Secara umum produk pertanian tidak selalu menguntungkan petani, disisi lain petani tidak memiliki banyak pilihan dan produksi harus terus berlanjut. Memilih produk yang tepat juga merupakan faktor penting bagi petani. Petani berusaha untuk menanam produk yang menghasilkan keuntungan paling banyak. Namun, faktor lain seperti kondisi alam, pemanfaatan tenaga kerja, dan biaya operasional mengakibatkan minimnya pendapatan bersih yang diperoleh petani.

Menurut Bongkang et al, (2019), besarnya pendapatan yang diterima petani melalui kegiatan usahataninya banyak ditentukan oleh perilaku petani itu sendiri dalam hal jenis cabang usahatani serta mempengaruhi faktor-faktor produksi seefektif dan seefisien mungkin. Selain itu juga iklim dan harga produk yang bersangkutan secara tidak langsung mempengaruhi pendapatan petani. Peningkatan pendapatan di sektor pertanian disebabkan karena pada umumnya penduduk Indonesia hidup dan dihidupkan dari usaha pertanian.

Di Kabupaten Lombok Timur mayoritas penduduknya merupakan petani. Selain padi dan jagung, para petani juga menanam sayuran sebagai komoditas pendamping. Salah satu tanaman sayuran yang cukup banyak di budidayakan di Kabupaten Lombok Timur yaitu tomat. Tomat merupakan produk pertanian yang tidak pernah kehilangan peminat. Mengingat pemanfaatannya sebagai bahan utama masakan, permintaan tomat akan selalu ada sepanjang tahun. Akan tetapi sifatnya yang mudah rusak menjadi penyebab sedikitnya keuntungan yang diperoleh petani, bahkan hingga mengalami kerugian. Kuranngya pemanfaatan dan penggunaan teknologi yang memadai menjadi penyebab minimnya kualitas dan kuantitas produksi, sehingga petani memiliki posisi tawar yang rendah (Amane, 2021). Akibatnya petani hanya menerima harga jual yang berlaku di pasaran. Ketika produksi yang rendah menyebabkan harga jual menjadi tinggi, dan sebaliknya ketika produksi melimpah harga jual akan menurun. Pada akhirnya produksi dan harga tomat mempengaruhi pendapatan dan kesejahteraan petani. Maka berdasarkan latar belakang tersebut, penulis tertarik untuk meneliti analisis kesejahteraan rumahtangga petani tomat di Kabupaten Lombok Timur. Penelitian ini bertujuan untuk; 1) mendeskripsikan profil rumahtangga petani tomat di Kabupaten Lombok Timur; 2) mengukur tingkat 
kesejahteraan petani tomat di Kabupaten Lombok Timur melalui pendekatan analisis pendapatan; 3) menganalisis tingkat kelayakan usahatani tomat di Kabupaten Lombok Timur.

\section{METODE PENELITIAN}

Penelitian ini dilakukan di Kabupaten Lombok Timur, karena merupakan salah satu daerah penghasil tomat di Provinsi Nusa Tenggara Barat (NTB). Pada penelitian ini telah ditentukan tiga Kecamatan sebagai lokasi penelitian secara purposive sampling yaitu Kecamatan Montong Gading, Kecamatan Pringgabaya dan Kecamatan Labuan Haji dengan pertimbangan kecamatan tersebut memiliki areal panen tanaman tomat yang cukup luas. Penentuan jumlah responden di lakukan secara Quota Sampling, yaitu ditetapkan sebanyak 40 orang petani sebagai responden. Sedangkan penentuan responden pada masing masing Kecamatan dilakukan secara proposional random sampling, sehingga di peroleh jumlah masing masing responden sebanyak 14 orang berasal dari Kecamatan Pringgabaya, 13 orang berasal dari Kecamatan Montong Gading, dan 13 orang berasal dari Kecamatan Labuan Haji.

Metode penelitian yang digunakan adalah metode observasi lapangan dengan pendekatan kualitatif - deskriptif. Teknik pengambilan sampel yang digunakan yaitu teknik survey dan wawancara menggunakan kuesioner. Penelitian kualitatif - deskriptif adalah prosedur penelitian yang menghasilkan data deskriptif berupa kata-kata tertulis atau lisan dari perilaku yang diamati (Creswell, 2002). Prosedur penelitian deskriptif dipilih dengan harapan hasil analisis yang dilakukan dapat dipaparkan secara jelas dan mudah dipahami. Data yang digunakan dalam penelitian ini adalah data primer dan data sekunder. Data primer diperoleh melalui wawancara dengan menggunakan daftar pertanyaan (kuisioner) kepada para petani tomat di Kabupaten Lombok Timur.

Untuk mendeskripsikan profil rumahtangga petani tomat di Kabupaten Lombok Timur menggunakan analisis deskriptif melalui wawancara yang dilakukan penulis dengan instrumen berupa kuesioner.

Untuk menganalisis tingkat kesejahteraan petani, digunakan alat analisis pendapatan dan analisis kelayakan finansial. Pada penelitian ini, tingkat pendapatan petani menggunakan rumus analisis pendapatan (Septiadi et al, 2020). Rumusnya adalah sebagai berikut;

$$
\pi=\mathrm{TR}-\mathrm{TC}
$$

$\mathrm{TR}=$ pendapatan petani tomat $(\mathrm{Rp} / \mathrm{Ha} / \mathrm{MT})$

$\mathrm{TC}=$ Biaya produksi petani tomat $(\mathrm{Rp} / \mathrm{Ha} / \mathrm{MT})$

$\pi=$ Pendapatan (keuntungan) petani tomat $(\mathrm{Rp} / \mathrm{Ha} / \mathrm{MT})$

Sedangkan untuk menganalisa tingkat kelayakan financial usahatani tomat digunakan analisa sebagai berikut (Sari et al, 2020).

$$
R /{ }_{C} \text { Ratio }=\frac{\text { Total Penerimaan }}{\text { Total Biaya Produksi }}=\frac{T R}{T C}
$$

Adapun kriteria yang digunakan adalah sebagai berikut :

1. Apabila nilai R/C Ratio > 1 berarti Usahatani tomat menguntungkan dan layak untuk diusahakan

2. Apabila nilai $\mathrm{R} / \mathrm{C}$ Ratio $<1$ berarti Usahatani tomat tidak menguntungkan dan tidak layak untuk diusahakan

3. Apabila nilai R/C Ratio $=1$ berarti Usahatani tomat Break Even Point. 


\section{HASIL DAN PEMBAHASAN}

\section{Karakteristik Usahatani Tomat di Kabupaten Lombok Timur.}

Tabel 1. Identitas petani sampel

\begin{tabular}{clc}
\hline No & \multicolumn{1}{c}{ Identitas Responden } & Keterangan \\
\hline 1 & Jumlah petani sampel (orang) & 40 \\
2 & Rata-rata umur (tahun) & 47 \\
3 & Rata-rata pendidikan formal (tahun) & 8 \\
4 & Rata-rata jumlah anggota keluarga (orang) & 4 \\
5 & Rata-rata pengalaman usaha tani (tahun) & 17 \\
6 & Rata-rata luas lahan tomat (are) & 16 \\
\hline
\end{tabular}

Sumber : data primer diolah (2021)

Pada Tabel 1 menggambarkan bahwa petani memiliki rata-rata berusia 47 tahun, artinya petani tomat di Kabupaten Lombok Timur masih termasuk dalam usia produktif. Menurut Mantra (2004), Simanjuntak (2005) dan Subri (2003) di Indonesia usia yang tergolong produktif berkisar pada usia 15 tahun sampai dengan 64 tahun. Berdasarkan tabel 1 kita ketahui bahwa rata rata responden petani tomat berusia 47 tahun yang tergolong petani yang masih produktif sehingga masih mampu mengelola dan menerima informasi informasi terkait dengan usahatani yang digeluti dalam hal ini yaitu usahatani tomat. Temuan ini mengkonfirmasi bahwa profesi petani masih eksis dimana usahatani tomat dikelola oleh masyarakat pada usia produktif.

Berdasarkan pada Tabel 1, Rata-rata petani menempuh pendidikan adalah Tamat Sekolah Dasar (8 tahun). Temuan penting yang menunjukkan rendahnya tingkat pendidikan petani tomat di Lombok Timur. Padahal menurut Manyamsari dan Mujiburrahmad (2014) pendidikan sangat menentukan tingkat kompetensi petani dalam melakukan kegiatan pertanian. Tingkat pendidikan petani tomat pada penelitian ini yang masih tergolong rendah menjadikan faktor penyebab utama mayoritas petani yang memilih perilaku nol resiko dalam pengembangan usahataninya. Pendidikan menjadi faktor penting dalam mempengaruhi keputusan petani dalam beradaptasi dengan perubahan lingkungan. Pendidikan merupakan faktor penting yang mempengaruhi pengambilan keputusan petani untuk beradaptasi dengan perubahan lingkungan. Penelitian yang dilakukan Anley et al. (2007) menyimpulkan bahwa peningkatan pendidikan dan lapangan kerja adalah kunci untuk mendorong partisipasi petani dalam adaptasi dan pengelolaan sumber daya alam yang inovatif. Dengan demikian, penting sekali bagi pihak yang berkepentingan dalam sektor pertanian dalam uapayanya meningkatkan pendidikan formal para petani sebagai manifestasi dari peningkatan sumberdaya manusia di sektor pertanian (Kasri, 2011).

Selain pendidikan, pelatihan dalam budidaya komoditas tomat juga harus diimplementasikan pada petani secara intensif. Menurut Astuthi (2018) menyatakan pemberdayaan petani adalah segala upaya untuk meningkatkan kemampuan petani untuk melaksanakan usahatani yang lebih baik melalui pendidikan dan pelatihan, penyuluhan dan pendampingan, pengembangan sistem dan pemasaran hasil pertanian. Pasca pelatihan petani lebih berani berinovasi, sehingga memiliki peluang untuk meningkatkan produksi usahatani. Ketersediaan informasi melalui penyuluhan dan pelatihan budidaya pertanian mempermudah pengambilan keputusan komparatif bagi petani dalam menjalankan usahatani. Tomat menjadi salah satu komoditas sayuran hortikultura yang sering ditanam oleh petani dan memiliki tingkat risiko yang cukup tinggi (Heriani et al, 2013), sehingga keberadaan pelatihan dalam budidaya masih 
sangat dibutuhkan.

Unit terkecil dari masyarakat yaitu keluarga yang terdiri dari beberapa anggota yaitu ayah,ibu serta anak anak . Jumlah anggota keluaraga menjadi salah satu penunjang keberhasilan dalam kegiatan ushatani. Dalam penelitian tentang usahatani tomat ini rata-rata responden memiliki jumlah anggota keluarga sebanyak 4 orang. Umumnya jumlah anggota keluarga responden pada penelitian ini selain terhitung sebagai tanggungan, juga berperan sebagai tenaga kerja atau biasa kita kenal dengan tenaga kerja dalam keluarga. Akan tetapi, dilain pihak terdapat konsekuensi, dimana semakin banyak anggota keluarga maka semakin banyak biaya yang diperlukan untuk memenuhi kebutuhan hidup kelurga. Hasrat petani untuk mencapai taraf kehidupan yangg lebih baik bagi keluarga, dalam banyak hal merupakan dorongan yang efektif untuk mempertinggi hasil usahatani (Talumingan, 2011). Adapun tidak semua anak-anak petani tidak mau terlibat dengan usahatani orang tuanya yang menggeluti profesi petani. Beberapa diantara keturunan petani memilih profesi di sektor non pertanian.

Petani memiliki pengalaman yang baik dalam usahatani tomat. Pada Tabel 1 dapat diketahui rata-rata petani sudah 17 Tahun menjalankan usahatani tomat tersebut. Banyaknya pengalaman yang dimiliki rata-rata petani tomat di Kabupaten Lombok Timur menjadi tanda positif bagi budidaya tomat di Kabupaten Lombok Timur. Hal sesuai dengan penelitian (Harahap et al, 2018) yang mengungkapkan pengalaman berusahatani dapat memepengaruhi kegiatan usahataninya, karena pengalaman petani memiliki peran yang sangat penting bagi petani dalam mengambil keputusan. Pengalaman juga memungkinan para petani untuk melihat semua peluang dan kendala yang akan dihadapi dalam usahatani mereka. Hal ini sesuai dengan pendapat Lamusa, (2010) semakin lama petani menggeluti usahataninya, maka akan semakin banyak pengalaman yang diterima. Sehingga dari lamanya pengalaman yang diperoleh akan membantu petani itu sendiri dalam mencegah kemungkinan kemungkinan yang menimbulkan kerugian pada usahatani. Rata-rata luas lahan yang dimiliki petani yang menjalankan usahatani tomat seluas 16 are, atau setara dengan 0,16 Hektar. Luas areal tomat tersebut memiliki luas yang serupa berdasarkan pada penelitian (Balkis et al, 2011) luas lahan dalam penelitian usahatani tomat di kelurahan Api Api kecamatan Bontang Utara bervariasi antara $0,10-0,50$ ha dengan status lahan milik sendiri. Selain itu dikatakan juga bahwa luas lahan tani sangat berpengaruh terhadap tingkat produktivitas petani.

\section{Analisis Finansial Usahatani Tomat}

Asumsi pada analisis finansial usahatani tomat yang digunakan pada penelitian ini diterapkan pada rata-rata luas lahan petani sebesar 16 are atau 0,16 hektar. Analisis yang digunakan adalah analisis pendapatan dan analisis tingkat kelayakan finansial usahatnai.

\section{Analisis Pendapatan}

\section{Biaya produksi usahatani}

Biaya produksi adalah semua pengeluaran atau pembiayaan yang digunakan untuk menghasilkan produksi tomat. Komponen biaya yang termasuk dalam biaya produksi pada usahatani tomat antara lain :

a) Biaya sarana produksi diukur dengan cara mengalikan jumlah sarana produksi fisik yang digunakan dengan harga persatuan. Biaya sarana produksi diantaranya adalah penggunaan bibit, pupuk dan obat-obatan. 
b) Biaya tenaga kerja adalah jumlah biaya upah atau upah tenaga kerja yang diukur berdasarkan ju mlah tenaga kerja dan banyaknya hari kerja atau jam kerja yang digunakan dikalikan dengan upah tenaga kerja dalam satuan hari kerja.

Tabel 2. Rata-rata biaya produksi pada usahatani tomat di kabupaten lombok

\begin{tabular}{|c|c|c|c|}
\hline No & Uraian & $\begin{array}{r}\text { Rata-Rata Biaya/ } \\
\text { musim tanam (Rp) }\end{array}$ & $\%$ \\
\hline 1 & Bibit & 400.763 & 14 \\
\hline 2 & Pupuk & 528.256 & 18 \\
\hline 3 & Obat-obatan & 272.500 & 10 \\
\hline 4 & Tenaga kerja & 1.694 .861 & 58 \\
\hline \multicolumn{2}{|c|}{ Jumlah } & 2.896 .381 & 100 \\
\hline
\end{tabular}

Sumber : data primer diolah (2021)

Berdasarkan Tabel 2, dapat diketahui bahwa proporsi paling besar untuk rata-rata biaya produksi usahatani tomat adalah biaya tenaga kerja dengan persentase sebanyak 57 persen, dengan rata-rata nominal sebesar Rp. 1.652.297. Sebagian besar tenaga kerja menggunakan tenaga kerja dari luar keluarga. Diantaranya adalah pengolahan lahan, pembibitan atau penyemaian, penanaman, pemeliharaan tanaman, pemanenan, dan pengolahan hasil. Komponen pengeluaran terbesar kedua untuk biaya produksi adalah biaya pembelian pupuk dengan kontribusi sebesar 18 persen dengan rata-rata nilai pengeluaran sebesar Rp. 527.550. Selebihnya Pengeluaran untuk bibit dan obat-obatan masing-masing berkontribusi sebesar 14 dan 9 persen.

2. Penerimaan

Penerimaan usahatani tomat dalam penelitian ini merupakan rata-rata penerimaan usahatani tomat per panen. Rata-rata penerimaan usahatani tomat dihitung dengan mengalikan antara rata-rata produksi tomat per panen dengan rata-rata harga tomat (Rupiah/kwintal). Penjelasan lebih detail ditunjukkan pada Tabel 3.

Tabel 3. Rata-rata penerimaan usahatani tomat d kabupaten Lombok timur

\begin{tabular}{ccl}
\hline No & \multicolumn{1}{c}{ Item } & \multicolumn{1}{c}{ Keterangan } \\
\hline 1 & Rata-rata produksi tomat/per panen & 20 kwintal \\
2 & Rata-rata harga tomat/ kwintal & Rp. 472.500 \\
\hline Rata-Rata Penerimaan Usahatani & Rp. 9.559 .038 \\
\hline
\end{tabular}

Sumber : data primer diolah (2021)

Berdasarkan Tabel 3, dapat diketahui bahwa rata-rata produksi usahatani tomat adalah sebanyak 20 kwintal per panen pada rata-rata luas lahan tomat 16 are atau 0,16 hektar. Sedangkan rata-rata harga tomat sebesar Rp. 472.500. Dengan demikian ratarata penerimaan usahatani tomat di Kabupaten Lombok Timur adalah sebesar Rp. 9.559.038. Nilai yang diperoleh pada penelitian usahatani tomat di Lombok timur ini tidak jauh berbeda dengan nilai hasil penelitian Talumingan et al, (2011) yang mengungkapkan bahwa rata rata penerimaan usahatani tomat di desa Tonsewer kecamatan Tompaso, Kabupaten Minahasa yaitu sebesar Rp 8.121.111. Nilai penerimaan usahatani pada penelitian usaha tani tomat di lombok timur tidak jauh berbeda dengan penelitian Tulumingan et al, (2011) dikarenakan luas lahan untuk menanam tomat tidak jauh berbeda yaitu sekitar 0,15-0,35 hektar.

3. Pendapatan

Pendapatan usahatani tomat merupakan nilai rata- rata penerimaan usahatani dikurangi rata-rata biaya produksi usahatani. 
Tabel 4. Rata-rata pendapata usahatani tomat di kabupaten Lombok timur

\begin{tabular}{ccc}
\hline No & Item & Keterangan \\
\hline 1 & Rata-rata penerimaan usahatani/Ha & 9.559 .038 \\
2 & Rata-rata biaya produksi usahatani/Ha & 2.896 .381 \\
\hline Rata-Rata Pendapatan Usahatani & $\mathbf{6 . 6 6 2 . 6 5 7}$ \\
\hline
\end{tabular}

Sumber: data primer diolah (2021)

Berdasarkan Tabel 4, dapat diketahui bahwa rata-rata penerimaan usahatani tomat adalah sebanyak Rp. 9.559.038. Sedangkan rata-rata biaya produksi usahatani tomat sebesar Rp. 2.896.381. Dengan demikian rata-rata pendapatan usahatani tomat di Kabupaten Lombok Timur adalah sebesar Rp. 6.662.657 yang mana pendapatan ini berniali positf atau mengalami keuntungan. Keuntungan yang didapat tersebut didapat pada satu kali musim tanam dan di budidayakan pada rata-rata luas lahan 16 are. Hasil penelitian ini sejalan dengan penelitian (Luntungan, 2015) yang mengungkapkan bahwa pendapatan bruto untuk usahatani tomat pada lahan kurang dari 1 hektar paling rendah di Kecamatan Tompaso Kabupaten Minahasa adalah sebesar Rp.7.500.000.

\section{Analisis Kelayakan Finansial Usahatani Tomat}

Tingkat kelayakan finansial usahatani tomat merupakan nilai rata- rata total penerimaan usahatani dibagi dengan rata-rata total biaya produksi.

Tabel 5. Tingkat kelayakan usahatani tomat di kabupaten Lombok timur

\begin{tabular}{cll}
\hline No & \multicolumn{1}{c}{ Keterangan } & Per Panen $(\mathrm{Rp})$ \\
\hline 1 & Rata-rata total penerimaan usahatani tomat/Ha & 9.559 .038 \\
2 & Rata-rata baya produksi usahatani tomat/Ha & 2.896 .381 \\
\hline Tingkat Kelayakan & $\mathbf{3 , 3}$
\end{tabular}

Sumber: data primer diolah (2021)

Berdasarkan Tabel 5, dapat diketahui bahwa rata-rata penerimaan usahatani tomat adalah sebanyak Rp. 9.559.038. Sedangkan rata-rata biaya produksi usahatani tomat sebesar Rp. 2.896.381, sehingga tingkat kelayakan usahatani tembakau di Kabupaten Lombok Timur adalah sebesar 3,3. Dengan demikian usahatani di Kabupaten Lombok Timur dinyatakan layak untuk dijalankan. Hal ini sejalan dengan penelitian (Dewi \& Indis, 2020) yang menyatakan bahwa usahatani tomat di Kabupaten Bangli layak untuk dijalankan dengan nilai tingkat kelayakan finansial 2,02.

\section{KESIMPULAN DAN SARAN}

\section{Kesimpulan}

Berdasarkan hasil penelitian dan analisis yang telah dilakukan, maka dapat ditarik kesimpulan sebagai berikut:

1. Usahatani tomat di Kabupaten Lombok Timur dinyatakan layak untuk diusahakan, karena berdasarkan analisis pendapatan, usahatani memperoleh rata-rata pendapatan (keuntungan) sebesar Rp 6.662.657 per panen/16 are, dan

2. Berdasarkan analisis tingkat kelayakan finansial, usahatani komoditas tomat di Kabupaten Lombok Timur dinyatakan layak untuk diusahakan dengan nilai R/C ratio sebesar 3,3.

\section{Saran}

Diharapkan petani Tomat di Kabupaten Lombok Timur dapat lebih memperhatikan penggunaan faktor produksi yang berpengaruh terhadap risiko produksi dan disesuaikan 
dengan standar penggunaan dalam usahatani.

\section{DAFTAR PUSTAKA}

Amane, G. S. (2021). Analisis Pendapatan dan Efisiensi Penggunaan Biaya Usahatani Tomat. Studi Kasus di Kecamatan Kapontori. Media Agribisnis, 5(1),23-28.

Anley, Y., Bogale, A. and Haile-Gabriel, A. (2007). Adoption decision and use intensity of soil and water conservation measures by smallholder subsistence farmers in Dedo District, Western Ethiopia. Land Degradation \& Development, 18(3), pp. 289-302. doi: 10.1002/ldr.775.

Astuthi, M. M. M. (2018). Pemberdayaan Petani Melalui Program Simantri di Kelompok Tani Tunjung Mekar. dwijenAGRO, 8(2), 86-90.

Bongkang, P. R. A., Pangemanan, P. A., \& Tangkere, E. G. (2019). Analisis Pendapatan Usahatani Tomat di Desa Taraitak Satu Kecamatan Langowan Utara. Journal of Agribusiness and Rural Development (Jurnal Agribisnis dan Pengembangan Pedesaan), 1(3).

Cahyono, B. (2008). Cabai Besar (Usahatani dan Penanganan Pasca panen). Kanisius: Yogyakarta.

Creswell, J. (2002). Educational research: Planning, conducting, and evaluating quantitative (Fourth; Matthew Buchholtz, ed.). Boston, USA: Pearson.

Dewi, K. A. C. J., \& Indis, Y. (2020). Faktor-Faktor Yang Mempengaruhi Pendapatan Usahatani Tomat (Studi Kasus di Desa Buahan, Kecamatan Kintamani, Kabupaten Bangli). dwijenAGRO, 10(2), 76-84.

Fitri, A., Harianto, H., \& Asmarantaka, R. W. (2018). Analisis Pendapatan Usahatani Sawi Pola Kemitraan dan Non Mitra di Kecamatan Megamendung Kabupaten Bogor Jawa Barat. Journal of Food System \& Agribusiness, 2(2), 94-99.

Harahap, J., Sriyoto, S., \& Yuliarti, E. (2018). Faktor-Faktor Yang Mempengaruhi Pengambilan Keputusan Petani Salak Dalam Memilih Saluran Pemasaran. Jurnal AGRISEP Kajian Masalah Sosial Ekonomi Pertanian dan Agribisnis, 17(1), 95-106.

Heriani, N., Zakaria, W. A., \& Soelaiman, A. (2013). Analisis keuntungan dan risiko usahatani tomat di Kecamatan Sumberejo Kabupaten Tanggamus. Jurnal Ilmu Ilmu Agribisnis: Journal of Agribusiness Science, 1(2).

Irsan, C. (2010). Keanekaragaman spesies kutudaun (Homoptera: Aphidoidea) dan musuh alaminya di tanaman hortikultura dan tumbuhan liar di wilayah Pagaralam dan sekitarnya. In Prosiding Seminar Nasional Perlindungan Tanaman, Bogor (pp. 5-6).

Kasri, R. A. (2011). Time series evidence on education and economic growth in Indonesia. Economic Journal of Emerging Markets, 3(2), pp. 109-123.

Mantra, I. B. (2004). Demografi Umum [General Demography]. Yogyakarta, Indonesia: Student Library.

Manyamsari, I., \& Mujiburrahmad, M. (2014). Karakteristik Petani Dan Hubungannya Dengan Kompetensi Petani Lahan Sempit (Kasus: Di Desa Sinar Sari Kecamatan Dramaga Kab. Bogor Jawa Barat). Jurnal Agrisep, 15(2), 58-74.

Sari, R., Nofialdi dan Putri, A. (2020). Financial feasibility of lime (citrus aurantifolia) farming in Tanah Datar District, West Sumatra. IOP Conference Series: Earth and Environmental Science, 583(1). doi: 10.1088/1755-1315/583/1/012016.

Septiadi, D., \& Nursan, M. (2020). Optimasi Produksi Usaha Tani Sebagai Upaya 
Peningkatan Pendapatan Petani Sayuran Di Kota Mataram. Agrifo: Jurnal Agribisnis Universitas Malikussaleh, 5(2), 87-96.

Septiadi, D., Rosmilawati, R., Usman, A., \& Hidayati, A. (2021). Kelayakan Finansial Usaha Tani Dan Persepsi Petani Terhadap Kebijakan Kenaikan Tarif Cukai Hasil Tembakau (Studi Kasus di Kecamatan Suralaga Kabupaten Lombok Timur). Jurnal Agrotek Ummat, 8(2), 91-98.

Simanjuntak, P. (2005). Pengantar Ekonomi Sumber Daya Manusia. Penerbit Fakultas Ekonomi UI, Jakarta.

Subri, M. (2003). Ekonomi sumber daya manusia. Divisi Buku Perguruan Tinggi, RajaGrafindo Persada.

Talumingan, C. (2011). Analisis Pendapatan Usahatani Tomat di Desa Tonsewer Kecamatan Tompaso Kabupaten Minahasa. AGRI-SOSIOEKONOMI, 7(3), 4351.

Tanaya, I. G. L. P., Rosmilawati, R., Hidayati, A., \& Septiadi, D. (2021). Analisis Risiko Produksi Spesialisasi Tanaman Hortikultura di Kabupaten Lombok Utara (Analysis of the Risk of Production for Horticultural Specialties in North Lombok Regency). Prosiding SAINTEK, 3, 315-327. 